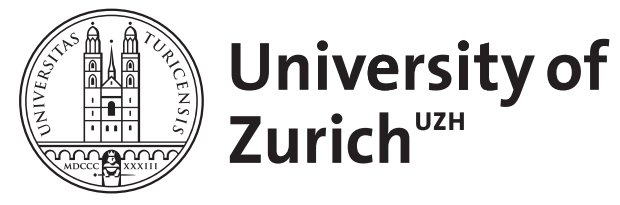

Zurich Open Repository and Archive

University of Zurich

University Library

Strickhofstrasse 39

CH-8057 Zurich

www.zora.uzh.ch

Year: 2001

\title{
Relation between average alcohol consumption and disease: an overview
}

\author{
Gutjahr, E ; Gmel, Gerhard ; Rehm, Jürgen
}

DOI: https://doi.org/10.1159/000050729

Posted at the Zurich Open Repository and Archive, University of Zurich

ZORA URL: https://doi.org/10.5167/uzh-94597

Journal Article

Published Version

Originally published at:

Gutjahr, E; Gmel, Gerhard; Rehm, Jürgen (2001). Relation between average alcohol consumption and disease: an overview. European Addiction Research, 7(3):117-127.

DOI: https://doi.org/10.1159/000050729 


\title{
Relation between Average Alcohol Consumption and Disease: An Overview
}

\author{
Elisabeth Gutjahr ${ }^{\mathrm{a}}$ Gerhard Gmel ${ }^{\mathrm{a}}$ Jürgen Rehm ${ }^{\mathrm{b}-\mathrm{d}}$ \\ a Swiss Institute for the Prevention of Alcohol and Drug Problems, Lausanne; bAddiction Research Institute, Zürich, \\ Switzerland; ' ${ }^{C}$ Centre for Addiction and Mental Health, and dUniversity of Toronto, Ont., Canada
}

\section{Key Words}

Alcohol · Acute consequences · Chronic disease . Overview • Volume of drinking · Patterns of drinking • Counterfactual scenario

\begin{abstract}
Objective: To conduct an overview of alcohol-related health consequences and to estimate relative risk for chronic consequences and attributable fractions for acute consequences. Methods: Identification of alcoholrelated consequences was performed by means of reviewing and evaluating large-scale epidemiological studies and reviews on alcohol and health, including epidemiological contributions to major social cost studies. Relative risks and alcohol-attributable fractions were drawn from the international literature and risk estimates were updated, whenever possible, by means of metaanalytical techniques. Results: More than 60 health consequences were identified for which a causal link between alcohol consumption and outcome can be assumed. Conclusions: Future research on alcohol-related health consequences should focus on standardization of exposure measures and take into consideration both average volume of consumption and patterns of drinking.
\end{abstract}

\section{Introduction}

Over the last decade, research on alcohol-related health consequences has rapidly expanded. Generally, studies assessing such consequences distinguish between chronic (e.g. cancers) and acute (e.g. accidents) outcomes [1]. Such a categorization seems to be practical as these two categories could be grossly distinguished by E-codes versus all other codes in the ICD-9. In addition, chronic consequences mainly related to long-term alcohol use are, in most cases, associated with the volume of drinking and assumed to be cross-culturally stable. In contrast, acute consequences were seen to be more influenced by drinking pattern (such as heavy episodic drinking) and cultural factors [2]. As a consequence alcohol-attributable fractions of chronic consequences were often derived by indirect methods which combine cross-culturally pooled meta-analytic risk estimates with country-specific prevalence of volume-oriented consumption categories. On the other hand attributable fractions of acute consequences influenced by the cultural environment and drinking pattern were usually assessed by direct methods (e.g., case counts of police records of drinking and driving [3]). Such a gross classification, however, is overly simple. For example, there is increasing evidence that (a) some 'chronic' consequences are more or at least evenly related to heavy episodic drinking $[4,5]$; (b) some 'acute' consequences such as suicides may be differently related to

\begin{tabular}{ll}
\hline KARGER & @ 2001 S. Karger AG, Basel \\
Fax +41 61 306 1234 $34-6877 / 01 / 0073-0117 \$ 17.50 / 0$ \\
$\begin{array}{l}\text { E-Mail karger@karger.ch } \\
\text { www.karger.com }\end{array}$ & $\begin{array}{l}\text { Accessible online at: } \\
\text { www.karger.com/journals/ear }\end{array}$
\end{tabular}

Gerhard Gmel, PhD

Swiss Institute for the Prevention of Alcohol and Drug Problems

14, avenue Ruchonnet, PO Box 870

$\mathrm{CH}-1001$ Lausanne (Switzerland)

Tel. +41 2132129 59, Fax +41 2132129 40, E-Mail ggmel@sfa-ispa.ch 
Table 1. Exclusively alcohol-related conditions

\begin{tabular}{ll}
\hline ICD-9 & Disease \\
\hline 291 & Alcoholic psychoses \\
303 & Alcohol-dependence syndrome \\
305.0 & Alcohol abuse \\
357.5 & Alcoholic polyneuropathy \\
425.5 & Alcoholic cardiomyopathy \\
535.3 & Alcoholic gastritis \\
$571.0-571.3$ & Alcoholic liver cirrhosis \\
790.3 & Excess blood alcohol \\
$980.0,980.1$ & Ethanol and methanol toxicity \\
\hline
\end{tabular}

both chronic heavy drinking, and acute episodes of intoxication $[6,7]$ or the association may differ across cultures ranging from negative to positive association [8], and (c) some chronic consequences can be assessed by direct methods (e.g. alcoholic dependence syndrome).

To summarize the state-of-the-art in the field of alcohol-related consequences, we compiled and evaluated recent scientific evidence. First, comprehensive overviews of the relationship between consumption and morbidity/ mortality, often undertaken as epidemiological input to social cost studies, were compared [9-16]. Completeness was also verified with other general overviews of health conditions related to alcohol consumption [17-20]. Since these studies differed greatly in their attribution of alcohol causality to health conditions, we set out to: (1) search for new evidence to clarify causality in relation to conditions on which existing mortality/morbidity studies were discordant; (2) suggest an up-to-date list of alcohol-related health conditions, and (3) offer pooled estimates of relative risks (RRs) or attributable fractions for those consequences, which were considered established.

\section{Methods}

\section{Identification of Consequences}

Identification of alcohol-related consequences was performed by means of reviewing and evaluating large-scale epidemiological studies on alcohol and health, including epidemiological input into major social cost and comprehensive reviews [9-21]. Scientific papers were collected primarily from the peer-reviewed, international literature. Following accepted guidelines established in the first major review [13], evidence was assessed according to methodological criteria such as quality of studies, relevance and strength of evidence, as well as biological plausibility. All conditions were included in the final list (tables 1-4), for which the evidence for a causal relationship with alcohol was conclusive [for more detailed information about the process of reviewing and evaluating the empirical evidence see, 22].

\section{Relative Risks and Attributable Fractions}

Some conditions such as alcoholic psychosis or alcohol dependence syndrome are, by definition, causally related and wholly attributable to alcohol (table 1). For most conditions, however, alcohol is a contributory rather than a sufficient cause [23]. Thus, a measure of the fraction of cases attributable to alcohol (alcohol-attributable fraction, AAF) is needed for each of these conditions. To determine attributable fractions a counterfactual scenario is required, that is a description of an alternative distribution of exposure, to which the actual distribution is contrasted [24]. The prevailing counterfactual scenario for alcohol as a risk factor is abstention (e.g. no alcohol at all), although other scenarios such as moderate consumption have been applied as well $[3,13]$. The AAF for chronic conditions are usually determined indirectly by combining RRs and prevalence data at different levels of consumption [for a detailed description of the method see, 10]. For the purpose of the present study, only RRs will be presented. RRs were drawn essentially from English et al. [13]. Risk estimates were updated whenever possible (e.g. for female breast cancer, diabetes, coronary heart disease) by inclusion of studies appearing since English et al. [13]. Pooling of several risk estimates was performed by means of precision-based weighting [13]. Methods and results of the pooling-procedure (meta-analysis) have been described in more detail elsewhere [22].

In contrast, the AAFs for acute consequences such as accidents and injuries are usually determined directly by assigning empirically given cases to alcohol whenever the responsible individual was under the influence of alcohol at the time of the event. To cite an example, road accidents are attributed to alcohol whenever the accidentresponsible driver tested positive for alcohol (e.g. at a blood alcohol concentration, BAC, of $>0.05 \%)$. As RR estimates are usually rare, for the purpose of the present study AAFs from the international literature $[10,13,22,25]$ were compared.

\section{Results}

To structure the presentation and discussion of results, we suggest that alcohol-related health consequences be categorized as follows: (1) chronic consequences, such as wholly alcohol-attributable consequences, cancer (neoplasm), cardiovascular disease, liver cirrhosis, effects of prenatal alcohol exposure and other chronic harms; (2) benefits of alcohol consumption, such as cardiovascular disease and other conditions, and (3) acute consequences, such as accidental injury and poisoning, suicide, interpersonal violence and assaults.

\section{Chronic Consequences of Drinking}

\section{Wholly Alcohol-Attributable Consequences}

With regard to the attribution of alcohol-relatedness, most unproblematic are those consequences that, by definition, are wholly alcohol-attributable $(\mathrm{AAF}=1$; table 1$)$. 
More complicated to assess are those consequences where alcohol plays a contributory role. These will be presented and discussed cause-specifically in the following sections.

\section{Cancer}

Oropharyngeal, Esophageal and Liver Cancer: Alcohol has consistently been related to the risk of cancer of the mouth (lip, tongue), pharynx, larynx, hypopharynx, esophagus and liver [1, 13, 17-19, 21]. The relationship between the average volume of alcohol consumption and cancer is usually characterized as being monotonically increasing but this may be partially an artifact of the methods [18]. Evidence for these cancers has accumulated from case-control and cohort studies. Recently, much emphasis has been put into the biochemical mechanisms to explain the carcinogenic behavior of alcohol in laboratory studies [19].

Female Breast Cancer. Much research has been conducted over the last decade on female breast cancer. In overviews prior to 1995 , it was most often concluded that evidence of a causal relationship with alcohol was insufficient $[26,27]$. However, recent studies and reviews have shown that not only hazardous or harmful but even moderate alcohol consumption can cause female breast cancer [9]. A meta-analysis by Smith-Warner et al. [28] found a clear linear relationship over the whole continuum of consumption. Other original studies supported this finding [21, 29-34]. In contrast to the weight of evidence, Zhang et al. [35] concluded from their investigation that moderate intake did not increase the risk of breast cancer, and that low drinking was associated with a protective effect. This finding, however, appears to be a notable outlier [36] and, so far, has not been corroborated by any further study. Recent studies focus on plausible biological mechanisms including alcohol's effect on hormones and tissue, alcohol's contribution to the initiation and progression/ promotion of breast cancer, but also alcohol's interaction with nutritional factors [19, 37].

Stomach, Pancreas, Colon, Rectum and Prostate Cancers. Furthermore, many recent research projects have investigated whether cancers of the stomach, pancreas, colon, rectum and prostate are alcohol-related. Overall, evidence for a causal relationship between alcohol and cancer of these sites, if any, was weak and inconclusive [37-50]. On prostate cancer, again most studies did not report observing an increased risk [51-54], whereas two cohort studies [55, 56] and one case-control study [57] reported a small increased risk in men who consume even moderate amounts of alcohol. Overall, evidence for a cau- sal relationship between alcohol and cancer of the stomach, pancreas, colon, rectum and prostate is so far not conclusive.

Major Salivary Glands, Ovarium, Endometrium and Bladder. Moreover, it has been hypothesized that alcohol might constitute a risk factor for cancer of the major salivary glands [58, 59], ovarium, endometrium [43, 60-62], and the bladder [43, 63-65]. For each of these sites, results were either scarce or heterogeneous, or the effects, if any, were found not to be statistically significant.

\section{Cardiovascular Disease}

The role of alcohol, as both a risk and protective factor for cardiovascular disease has been studied extensively in the past decade. As far as coronary heart disease (CHD) is concerned, the effect of moderate alcohol consumption clearly is a beneficial one. Furthermore, most studies suggest that low-level consumption equally offers some protection against stroke, particularly ischemic stroke. The benefits of alcohol consumption on both stroke and CHD are therefore discussed in the following section. In contrast, hypertension and other cardiovascular disorders such as cardiac arrhythmias and heart failure as well as ill-defined descriptions and complications of heart disease are adversely affected by alcohol [4, 66-69]. The weight of evidence suggests that hazardous and harmful levels of consumption cause hypertension in both men and women [13, 70-74]. Low-level intake, however, was not associated with hypertension in men, while it conferred a small protective effect in women $[13,72]$.

\section{Liver Cirrhosis}

Alcohol is regarded as the leading cause of cirrhosis in established market economies [13, 75-77]. Whereas the association with alcoholic liver cirrhosis is clear with all cases being attributable to alcohol, debate remains whether this equally applies to unspecified liver cirrhosis. Several authors contend that, empirically, it is extremely difficult to separate alcoholic from unspecified liver cirrhosis and that the term 'unspecified liver cirrhosis' is applied when no specific etiological factor is reported or identified [13]. Research in the USA indicated that an appreciable proportion of cirrhosis deaths without mention of alcohol was in fact attributable to alcohol [78]. On the other hand, to apply AAFs of liver cirrhosis to other countries can be extremely misleading. In many countries (e.g. China or India) liver cirrhoses are caused by other factors such as viral infections. The corresponding AAFs have been shown to vary between less than 10\% (China) and 90\% (Finland) [1]. 
Table 2. Chronic alcohol-related health effects with relative risks

\begin{tabular}{|c|c|c|c|c|c|c|c|}
\hline \multirow[t]{3}{*}{ Disease } & \multirow{3}{*}{$\begin{array}{l}\text { ICD-9 } \\
\text { intake }\end{array}$} & \multicolumn{6}{|l|}{$\mathrm{RR}$} \\
\hline & & \multicolumn{2}{|l|}{ low } & \multicolumn{2}{|c|}{ hazardous } & \multicolumn{2}{|l|}{ harmful } \\
\hline & & females & males & females & males & females & males \\
\hline Lip and oropharyngeal cancer & $140,141,143-146,148,149,230.0$ & 1.45 & 1.45 & 1.85 & 1.85 & 5.39 & 5.39 \\
\hline Esophageal cancer & $150,230.1$ & 1.80 & 1.80 & 2.38 & 2.38 & 4.36 & 4.36 \\
\hline Liver cancer & $155,230.8$ & 145 & 1.45 & 3.03 & 3.03 & 3.60 & 3.60 \\
\hline Laryngeal cancer & $161,231.0$ & 1.83 & 1.83 & 3.90 & 3.90 & 4.93 & 4.93 \\
\hline Female breast cancer & $174,233.0$ & 1.08 & - & 1.30 & - & 1.66 & - \\
\hline Epilepsy & 345 & 1.34 & 1.23 & 7.22 & 7.52 & 7.52 & 6.83 \\
\hline Hypertension & $401-405$ & 0.85 & 1.02 & 1.27 & 1.43 & 1.79 & 2.05 \\
\hline Cardiac arrhythmias & $427.0,427.2,427.3$ & 1.51 & 1.51 & 2.23 & 2.23 & 2.23 & 2.23 \\
\hline Heart failure & $428-429$ & $*$ & $*$ & $*$ & $*$ & $*$ & $*$ \\
\hline Esophageal varices & $456.0-456.2$ & 1.26 & 1.26 & 9.54 & 9.54 & 9.54 & 9.54 \\
\hline Gastroesophageal hemorrhage & 530.7 & n.a. & n.a. & n.a. & n.a. & n.a. & n.a. \\
\hline Unspecified liver cirrhosis & $571.5-571.9$ & 1.26 & 1.26 & 9.54 & 9.54 & 9.54 & 9.54 \\
\hline Acute and chronic pancreatitis & $577.0,577,1$ & n.a. & n.a. & n.a. & n.a. & n.a. & n.a. \\
\hline Spontaneous abortion & 634 & 1.20 & - & 1.76 & - & 1.76 & - \\
\hline Low birth weight & 656.5 & 0.89 & 0.89 & 1.62 & 1.62 & 1.62 & 1.62 \\
\hline Psoriasis & 696.1 & 1.58 & 1.58 & 1.60 & 1.60 & 2.20 & 2.20 \\
\hline Prematurity & 764 & 0.93 & 0.93 & 1.36 & 1.36 & 1.36 & 1.36 \\
\hline Intrauterine growth retardation & 765 & 0.99 & 0.99 & 1.68 & 1.68 & 1.68 & 1.68 \\
\hline
\end{tabular}

n.a. $=$ Relative risks not applicable because the attributable fraction was obtained by a direct method: $530.7=0.47 ; 577.0=1.00 ; 577.1=0.84$

* Heart failure-attributable fraction determined indirectly from other circulatory diseases.

\section{Effects of Prenatal Alcohol Exposure}

Today, there is ample evidence that alcohol consumption during pregnancy is related to various risks to the fetus which include gross congenital anomalies and fetal alcohol syndrome [79-92]. Fetal alcohol syndrome has been characterized as a continuum, with minor physical malformations at one end and serious neurobiological dysfunctions including mental retardation on the other end [93]. The prenatal teratogenic effects of alcohol also include lethal consequences such as spontaneous abortion, low birth weight, fetal damage and premature/intrauterine growth-retardation $[62,94,95]$ even at low levels of average consumption during the first trimester of pregnancy.

\section{Other Chronic Conditions}

Other risks of alcohol consumption currently discussed in the literature are epilepsy [96-98], acute and chronic pancreatitis and psoriasis. Whereas for pancreatitis the causal role of alcohol seems to be clear, Skinazi et al. [99] and Amman et al. [100] contend that the discrimination between acute and chronic pancreatitis is not justifiable since the overwhelming majority of patients presenting with acute pancreatitis have at the same time an underlying chronic pancreatitis [101, 102]. On psoriasis, our search did not yield any recent studies. English et al. [13] found that the results of the pooled estimates were consis- tent with a moderately strong and statistically significant effect.

Given that the chronic consequences discussed above are caused not only by alcohol but by other factors as well, it is necessary to estimate the likelihood of alcohol causation (by means of RRs). Table 2 summarizes the evidence on alcohol-related chronic consequences and presents the respective RRs at different levels of consumption.

\section{Benefits of Alcohol Consumption}

\section{Cardiovascular Disease}

CHD is one of the leading causes of death in established market economies and developing countries [103]. At the same time, the most important health benefits of alcohol have been found in the area of CHD at low to moderate levels of consumption [18, 72, 104-111]. Only a few studies have failed to substantiate this association in men [112] or women [113, 114]. Some studies found that alcohol may offer protection against CHD not only at low to moderate intake but across the continuum of alcohol consumption [71, 115-119]; they nevertheless show that most of the protective effect is gained at low levels of consumption such as one drink every other day. Furthermore, the relationship appears to be associated with par- 
Table 3. Beneficial alcohol-related health effects with relative risks

\begin{tabular}{|c|c|c|c|c|c|c|c|}
\hline \multirow[t]{3}{*}{ Disease } & \multirow{3}{*}{$\begin{array}{l}\text { ICD-9 } \\
\text { intake }\end{array}$} & \multicolumn{6}{|l|}{$\mathrm{RR}$} \\
\hline & & \multicolumn{2}{|l|}{ low } & \multicolumn{2}{|c|}{ hazardous } & \multicolumn{2}{|l|}{ harm } \\
\hline & & females & males & females & males & females & males \\
\hline Diabetes & 250 & 0.92 & 0.99 & 0.87 & 0.57 & 1.13 & 0.73 \\
\hline Coronary heart disease & $410-414$ & 0.82 & 0.82 & 0.83 & 0.83 & 0.88 & 0.88 \\
\hline Stroke & $430-438$ & 0.59 & 0.69 & 0.51 & 0.95 & 7.72 & 1.79 \\
\hline Cholelithiasis & 574 & 0.82 & 0.82 & 0.68 & 0.68 & 0.50 & 0.50 \\
\hline
\end{tabular}

ticular patterns of drinking $[4,120,121]$. The biological mechanisms explaining the protective effect of alcohol are, for example, increased high-density cholesterol levels and antithrombotic effects [1,122-125]. To date, the crucial point in assessing the effect of alcohol on CHD remains hazardous consumption [118].

\section{Other Conditions}

Cerebrovascular disease (stroke) comprises two essential subtypes which are differently affected by alcohol. As far as ischemic stroke is concerned, the predominant type of stroke, the weight of evidence including biological mechanisms suggests similar effects as for CHD, namely that low to moderate consumption may offer some protection [71, 74, 105, 116, 126-130]. Concerning hemorrhagic stroke, the weight of evidence suggests an increase in risk even at low levels of consumption [126, 131-133].

Furthermore, alcohol may offer some protection against diabetes and cholelithiasis (gallstones). The Australian meta-analysis by English et al. [13] concluded that there was some evidence that alcohol may protect against the onset of diabetes. Since then, the findings from a cohort of more than 40,000 male health professionals showed that moderate alcohol consumption may decrease the risk of diabetes, perhaps through the effects of alcohol on insulin sensitivity [134]. In addition, findings from the British Regional Heart Study indicated a protective effect [135]. Further, in a follow-up of men enrolled in the US Physicians Study a marked negative association of incident diabetes with alcohol consumption was shown [136]. In a recent prospective study, a U-shaped association between alcohol and type-II diabetes was found [137].

However, Kao et al. [138] found that, in women but not in men, there was evidence (based on small numbers) of an inverse relationship between alcohol consumption and the risk of diabetes. Indeed, men consuming more than 21 drinks per week were at increased risk of diabetes.
A protective effect of moderate alcohol consumption against diabetes may be mediated through the effects of alcohol on glucose tolerance and insulin resistance. Moderate alcohol drinking has been shown to increase insulin sensitivity [139-141] and lower insulin resistance [142], even in young adult drinkers [143]. In summary, there is growing evidence from cohort studies that moderate alcohol consumption reduces the risk of diabetes and a plausible underlying biological mechanism has been identified.

With regard to cholelithiasis (gallstones) there is some evidence that alcohol may offer some protection against gallstones [13, 72]. These findings have been substantiated by recent large-scale cohort and case-control studies which reported an inverse relationship [144-147]. Table 3 gives an overview of diseases on which alcohol has potentially beneficial effects.

\section{Acute Consequences}

\section{Accidental Injury and Poisoning, Suicide,}

\section{Interpersonal Violence and Assaults}

Alcohol use has been associated with increased risk of traumatic injury in a variety of settings such as traffic accidents, accidents in professional and recreational contexts, falls, arson, but also self-inflicted injury (including suicide) and injuries resulting from interpersonal violence $[68,148,149]$. The assessment of causality is often difficult and needs triangulation by different sources, such as time series analyses, natural experiments, case-control studies, emergency-room studies, general population surveys, and experimental designs [150]. The context of drinking, social and cultural environment, and drinking patterns, however, is probably as important as the amount of alcohol consumed. To give an example, studies on violent incidents have repeatedly shown that alcohol consumption precedes violent events and the amount of 
Table 4. Acute alcohol-related health effects with attributable fractions from international comparisons

\begin{tabular}{|c|c|c|c|c|c|c|c|c|c|}
\hline \multirow[t]{2}{*}{ Diseases } & \multirow[t]{2}{*}{ ICD-9 } & \multicolumn{2}{|c|}{$\begin{array}{l}\text { De Bakey et al. [25] } \\
\text { USA }\end{array}$} & \multicolumn{2}{|c|}{$\begin{array}{l}\text { English et al. [13] } \\
\text { Australia }\end{array}$} & \multicolumn{2}{|c|}{$\begin{array}{l}\text { Single et al. [10] } \\
\text { Canada }\end{array}$} & \multicolumn{2}{|c|}{$\begin{array}{l}\text { Gutjahr and Gmel [22] } \\
\text { Switzerland }\end{array}$} \\
\hline & & females & males & females & males & females & males & females & males \\
\hline Traffic accident injuries & E810-E819 & 0.42 & 0.42 & $0.00-0.34$ & $0.18-0.43$ & 0.43 & 0.43 & $0.00-0.34$ & $0.18-0.42$ \\
\hline Non-traffic accident injuries & E820-E825 & 0.42 & 0.42 & $0.00-0.34$ & $0.18-0.43$ & 0.43 & 0.43 & $0.00-0.34$ & $0.18-0.42$ \\
\hline Bicycle accident injuries & E826 & 0.20 & 0.20 & $0.00-0.34$ & $0.18-0.43$ & 0.20 & 0.20 & $0.00-0.34$ & $0.18-0.42$ \\
\hline Other road vehicle accident injuries & E829 & 0.20 & 0.20 & $0.00-0.34$ & $0.18-0.43$ & 0.2 & 0.20 & $0.00-0.34$ & $0.18-0.42$ \\
\hline Water transport accident injuries & E830-E839 & 0.20 & 0.20 & $*$ & $*$ & 0.20 & 0.20 & 0.20 & 0.20 \\
\hline Air-space transport accident injuries & E840-E845 & 0.16 & 0.16 & $*$ & $*$ & 0.16 & 0.16 & 0.16 & 0.16 \\
\hline Accidental ethanol and methanol poisoning & E860.0-E860.2 & 1.00 & 1.00 & 1.00 & 1.00 & 1.00 & 1.00 & 1.00 & 0.10 \\
\hline Accidental fall injuries & E880-E888 & 0.35 & 0.35 & 0.34 & 0.34 & $0.13-0.34$ & $0.20-0.34$ & $0.13-0.34$ & $0.20-0.34$ \\
\hline Arson injuries & E890-E899 & 0.45 & 0.45 & 0.44 & 0.44 & 0.38 & 0.38 & 0.38 & 0.38 \\
\hline Accidental excessive cold & E901 & 0.25 & 0.25 & $*$ & $*$ & 0.25 & 0.25 & 0.25 & 0.25 \\
\hline Accidental drowning & E910 & 0.38 & 0.38 & $0.03-0.50$ & $0.03-0.50$ & $0.01-0.50$ & $0.01-0.50$ & $0.01-0.38$ & $0.01-0.38$ \\
\hline Accidental aspiration & E911 & 0.25 & 0.25 & 1.00 & 1.00 & 0.25 & 0.25 & 0.25 & 0.25 \\
\hline Striking against/struck by objects & E917 & 0.25 & 0.25 & $*$ & $*$ & 0.07 & 0.07 & 0.07 & 0.07 \\
\hline Caught in/between objects & E918 & 0.25 & 0.25 & $*$ & $*$ & 0.07 & 0.07 & 0.07 & 0.07 \\
\hline Occupational and machine injuries & E919-E920 & 0.25 & 0.25 & 0.07 & 0.07 & 0.07 & 0.07 & 0.07 & 0.07 \\
\hline Accidental firearm missile injuries & E922 & 0.25 & 0.25 & $*$ & $*$ & 0.25 & 0.25 & 0.25 & 0.25 \\
\hline Suicide, self-inflicted injuries & E950-E959 & 0.28 & 0.28 & $0.02-0.10$ & $0.02-0.15$ & $0.11-0.19$ & $0.23-0.31$ & $0.02-0.10$ & $0.02-0.15$ \\
\hline Victim, fight, brawl, rape & E960 & 0.46 & 0.46 & 0.47 & 0.47 & 0.27 & 0.27 & 0.27 & 0.27 \\
\hline Victim assault firearms & E965 & 0.46 & 0.46 & 0.47 & 0.47 & 0.27 & 0.27 & 0.27 & 0.27 \\
\hline Victim assault cutting instrument & E966 & 0.46 & 0.46 & 0.47 & 0.47 & 0.27 & 0.27 & 0.27 & 0.27 \\
\hline Victim child battering & E967 & 0.46 & 0.46 & 0.16 & 0.16 & 0.16 & 0.16 & 0.16 & 0.16 \\
\hline Victim assault other & E968 & 0.46 & 0.46 & 0.47 & 0.47 & 0.27 & 0.27 & 0.27 & 0.27 \\
\hline Late effects of injuries by another & E969 & 0.46 & 0.46 & 0.47 & 0.47 & 0.27 & 0.27 & 0.27 & 0.27 \\
\hline
\end{tabular}

Ranges refer to age-specific attributable fractions whereby minimum and maximum estimates are shown.

* No AAFs provided by the authors.

drinking is related to the severity of subsequent violence, pointing to causality in standard epidemiological terms [151]. The bar atmosphere, expectancies of alcohol effects, and the social and cultural environment 'permitting' alcohol to disinhibit norms are highly important [6, 19] to alcohol becoming a 'cause' of violent events. Overall, in the literature on alcohol-related mortality and morbidity, there is a broad consensus that alcohol plays a causal role in the events summarized in table 4.

Although some causal role of alcohol for acute consequences can be assumed, some very important methodological issues need to be clarified when it comes to quantifying the fractions of consequences attributed to alcohol [152]. For example, accidents are often attributed to alcohol whenever the responsible individual tested BAC-positive. However, from a strict epidemiological point of view, blood or breath tests can give only an indication of an association; since it cannot be determined how many such accidents would have happened even without drinking, it is virtually impossible to determine precisely the role of alcohol in these events [21, 153]. Clearly, in reviews of experimental studies $[154,155]$ psychophysical functions showed deficits already at BAC levels of about $0.03-0.05 \mathrm{~g} / 100 \mathrm{ml}$ and deficits increased with increasing levels which explained the mechanism of alcohol contribution for accidents. However, an elevated BAC level alone is not a sufficient indicator for alcohol being the cause of an accident, and hence AAFs determined by BAC thresholds are usually biased.

\section{Discussion}

The present paper is aimed at summarizing and updating the available evidence on alcohol-related consequences and the quantification of the alcohol attribution of established consequences. Of course, the list of established conditions presented here is not a definitive list of alcoholrelated consequences. Rather, it should be regularly updated in the light of ongoing research and the appearance of new evidence. Biological evidence plays a key role here, as some of the consistent associations between alcohol and disease are currently refused because of the lack of biological plausibility (e.g. alcohol and lung cancer). 
Besides establishing causality, the quantification of the $\mathrm{AAF}$ is at least of equal importance for the estimation of alcohol-related burden. For consequences, which are assumed to be stable across cultures and related mainly to total volume of consumption, the pooling of studies primarily needs comparable exposure levels (besides quality of research design and publishing of relevant statistics) [115]. Studies, however, often differ greatly with respect to assessment of exposure. For example, levels depicted as a moderate intake often are not comparable. Standardization of exposure levels, e.g. those used by English et al. [13], would further help meta-analytical reviews and more stable estimation of RRs.

For many of the alcohol-related consequences, substantial evidence has been accumulated that patterns of drinking are equally important as predictors of both chronic and acute health outcomes [4, 5, 121, 156]. For example, cardiovascular disease as a chronic outcome is also influenced by the pattern of drinking $[4,157]$. Thus, an investigation by McElduff and Dobson [120] showed that a pattern of moderate regular drinking was associated with a reduction in risk of CHD when compared to abstainers, whereas binge drinkers displayed an increased risk. Similarly Walsh and Rehm [158] showed for a range of consequences that the same amount of alcohol was more detrimental when drank in a more irregular manner.

The impact of drinking patterns on the risk of consequences, as well as the protective effect for some consequences at lower levels, raises the question of the counterfactual scenario to calculate AAFs. Commonly, abstention is used as counterfactual. Hence, the alcohol-attributable burden estimated by means of AAF and calculated under this scenario estimates the burden that could be avoided if everybody in a population switched to no consumption at all. Such a scenario widely avoids arguments about whether drinking patterns should be included in determining the RRs as all drinking would disappear. The avoidable burden from patterns of drinking would be attributed to the respective categories of volume of drinking [see the recent literature about refining the preventive paradox, e.g. 159, 160].

The usefulness of abstinence as the counterfactual (or the theoretical minimum) [3], on the other hand, can be questioned on several grounds. First, total abstinence of a population is an unrealistic scenario for most countries in the world (maybe with the exception of some countries where abstinence and prohibition are religiously motivated). Hence, from a public health point of view abstinence may be difficult to communicate in most countries, especially as the preventive message of moderate consumption for the heart has reached a wide audience [161]. Second, abstinence as a counterfactual would also underestimate the avoidable burden at least in established market economies, as the 'prevented' burden would partly counterbalance the 'caused' burden. In countries in which the prevention of CHD plays a minor role, however, probably more burden would be avoided with abstinence as the counterfactual compared with, e.g., moderate consumption as the counterfactual [103].

On the other hand, the use of a moderate volume of drinking as a counterfactual scenario [13] is also questionable. First, as drinking patterns modify the association between the volume of drinking and health consequences [3], a counterfactual scenario defined by volume only would underestimate the avoidable burden. Second, some acute consequences (e.g. accidents) have higher risks even at moderate levels of consumption and the question is not whether an individual should be abstinent or a moderate consumer, but whether he or she should abstain in certain risky situations. Other acute consequences are more closely related to heavy occasional drinking than volume of drinking as well as to environmental and socio-cultural factors [20].

To summarize, a single counterfactual scenario may not be equally well applicable to all consequences and in all cultures. In addition to modeling the attributable burden as deviation from abstinence, different scenarios should be integrated and sensitivity analyses should be performed.

However, without sufficient data such discussions are mainly theoretical and do not lead to any solutions. The use of patterns of drinking in epidemiological research is still scarce, and focus is often placed on the (average) volume of drinking only [162]. To integrate patterns of drinking in a comparative risk assessment, worldwide standardized measures of exposure, including volume and patterns of drinking, are urgently needed. Moreover, the proportion of mortality and morbidity stemming from acute consequences is at least as important as that from chronic consequences, not only in young people [9]. With the exception of some countries (mainly the Scandinavian countries, Canada, USA, Australia), for which the share of the global burden of disease is small in comparison to countries such as China, India, or Brazil, data and estimates on AAFs for acute problems are rare. Therefore AAFs from other countries are often applied to those countries for which data are lacking, despite the knowledge that the cultural environment is of particular importance for such consequences. 
In conclusion, research on alcohol-related health outcomes at present not only needs to take into consideration both the average (volume) consumption and patterns of drinking and to standardize the assessment of exposure, it also needs to conduct studies on those outcomes which are culturally co-determined to a large extent, especially in developing and emerging countries.

\section{Acknowledgments}

Some of the present study was undertaken for the report 'The Social Costs of Alcohol Consumption in Switzerland' and has received financial support from the Swiss Federal Office of Public Health (grant No. 98-000794/8120). The authors would like to thank the Swiss Institute for the Prevention of Alcohol and Other Drug Problems, especially Elisabeth Grisel, for technical assistance.

\section{References}

1 World Health Organization: International Guide for Monitoring Alcohol Consumption and Related Harm. Copenhagen, World Health Organization, Department of Mental Health and Substance Dependence, Noncommunicable Diseases and Mental Health Cluster, 2000.

2 Rehm J, Ashley MJ, Room R, Single E, Bondy SJ, Ferrence R, Giesbrecht N: On the emerging paradigm of drinking patterns and their social and health consequences. Addiction 1996;91: 1615-1621.

3 Rehm J, Monteiro MG, Room R, Gmel G, Jernigan D, Frick U, Graham K: Steps towards constructing a global comparative risk analysis for alcohol consumption: Determining indicators and empirical weights for patterns of drinking, deciding about theoretical minimum, and dealing with different consequences. Eur Addict Res 2001;7:137-146.

4 Puddey IB, Rakic V, Dimmitt SB, Beilin LJ: Influence of pattern of drinking on cardiovascular disease and cardiovascular risk factors A review. Addiction 1999;94:649-663.

5 Rehm J, Greenfield TK, Rogers JD: Average volume of alcohol consumption, patterns of drinking and all-cause mortality. Results from the US National Alcohol Survey. Am J Epidemiol 2001;153:64-71.

6 Rossow I, Pernanen K, Rehm J: Accidents, suicide and violence; in Klingemann $\mathrm{H}$, Gmel G (eds): Mapping the Social Consequences of Alcohol Consumption. Dordrecht, Kluwer Academic Press, 2001, pp 93-112.

7 Midanik LT, Tam T, Greenfield TK, Caetano R: Risk functions for alcohol-related problems in a 1988 US national sample. Addiction 1996; 91:1427-1437.

8 Ramstedt M: Alcohol and suicide in 14 European countries. Addiction 2001;96(suppl 1): 59-75.

9 Single E, Robson LS, Rehm J, Xie X: Morbidity and mortality attributable to alcohol, tobacco, and illicit drug use in Canada. Am J Public Health 1999;89:385-390.

10 Single E, Robson L, Xie X, Rehm J: The Costs of Substance Abuse in Canada. Ottawa, Canadian Centre on Substance Abuse, 1996.

11 Harwood H, Fountain D, Livermore G, The Lewin Group: The Economic Costs of Alcohol and Drug Abuse in the United States, 1992 Rockville, US Department of Health and Human Services, National Institute on Drug Abuse (NIDA), 1998.
12 Devlin NJ, Scuffham PA, Bunt LJ: The social costs of alcohol abuse in New Zealand. Addiction 1997;92:1491-1505.

13 English DR, Holman CDJ, Milne E, Winter MG, Hulse GK, Codde JP, Bower CI, Corti B, De Klerk N, Knuiman MW, Kurinczuk JJ, Lewin GF, Ryan GA: The Quantification of Drug Caused Morbidity and Mortality in Australia, 1995. Canberra, Commonwealth Department of Human Services and Health, 1995.

14 Stinson FS, Dufour M, C., Steffens RA, DeBakey S: Alcohol-related mortality in the United States, 1979-1989. Alcohol Health Res World 1993; 17:251-260.

15 Collins D, Lapsley H: Estimating the Economic Costs of Drug Abuse in Australia. Canberra, Commonwealth of Australia, 1991, vol 15.

16 Rice DP, Kelman S, Miller LS: The economic cost of alcohol abuse. Alcohol Health Res World 1991;15:307-316.

17 Gurr M: Alcohol: Health Issues Related to Alcohol Consumption, ed 2. Brussels, ILSI Europe, 1996.

18 Single E, Ashley MJ, Bondy SJ, Rankin J, Rehm J, with the assistance of Dobbins M: Evidence Regarding the Level of Alcohol Consumption Considered to Be Low-Risk for MEN and Women. Canberra, Australian Commonwealth Department of Health and Aged Care, 1999.

19 US Department of Health and Human Services: 10th Special Report to the US Congress on Alcohol and Health: Highlights from Current Research. Rockville, US Department of Health and Human Services, Public Health Service, National Institutes of Health, National Institute on Alcohol Abuse and Alcoholism, 2000.

20 Klingemann H, Gmel G: Mapping the Social Consequences of Alcohol Consumption. Dordrecht, Kluwer Academic Press, 2001.

21 Corrao G, Bagnardi V, Zambon A, Arico S: Exploring the dose-response relationship between alcohol consumption and the risk of several alcohol-related conditions: A meta-analysis. Addiction 1999;94:1551-1573.

22 Gutjahr E, Gmel G: Die sozialen Kosten des Alkoholkonsum in der Schweiz: Epidemiologische Grundlagen 1995-1998. Forschungsbericht 36. Lausanne, Schweizerische Fachstelle für Alkohol- und andere Drogenprobleme, 2001.
23 Rothman KJ, Greenland S, (eds): Modern Epidemiology, ed 2. Philadelphia, LippincottRaven Press, 1998.

24 Murray CJL, Lopez A: On the comparable quantification of health risks: Lessons from the Global Burden of Disease Study. Epidemiology 1999; 10:594-605.

25 DeBakey S, Stinson FS, Dufour MC: Surveillance Report 25. Cirrhosis Mortality in the United States. Rockville, US Department of Health and Human Services, National Institute on Alcohol Abuse and Alcoholism, Division of Biometry and Epidemiology, 1993.

26 Rosenberg L, Metzger LS, Palmer JR: Alcohol consumption and risk of breast cancer: A review of the epidemiologic evidence. Epidemiol Rev 1993;15:133-144.

27 Schatzkin A, Longnecker MP: Alcohol and breast cancer: Where are we now and where do we go from here. Cancer 1994;74:1101-1110.

28 Smith-Warner SA, Spiegelman D, Yaun S-S, Van den Brandt PA, Folsom AR, Goldbohm RA, Graham S, Holmberg L, Howe GR, Marshall JR, Miller AB, Potter JD, Speizer FE, Willett WC, Wolk A, Hunter DJ: Alcohol and breast cancer in women: A pooled analysis of cohort studies. JAMA 1998;279:535-540.

29 Bowlin SJ, Leske MC, Varma A, Nasca P, Weinstein A, Caplan L: Breast cancer risk and alcohol consumption: Results from a large casecontrol study. Int J Epidemiol 1997;26:915923.

30 Royo-Bordonada MA, Martín-Moreno JM, Guallar E, Gorgojo L, Van't Veer P, Mendez M, Huttunen JK, Martin BC, Kardinaal AF, Fernández-Crehuet $\mathrm{J}$, Thamm M, Strain JJ, Kok FJ, Kohlmeier L: Alcohol intake and risk of breast cancer: The Euramic Study. Neoplasma 1997;44:150-156.

31 Swanson CA, Coates RJ, Malone KE, Gammon MD, Schoenberg JB, Brogan DJ, McAdams M, Potischman N, Hoover RN, Brinton LA: Alcohol consumption and breast cancer risk among women under age 45 years. Epidemiology 1997;8:231-237.

32 Wingo PA, Calle EE, Thun MJ, Murray T, Henley J, Heath CW Jr: Alcohol consumption and the risk of fatal breast cancer in a prospective cohort of United States women. Am J Epidemiol 1997;145:S28. 
33 Van den Brandt PA, Goldbohm RA, Van't Veer P: Alcohol and breast cancer: Results from the Netherlands Cohort Study. Am J Epidemiol 1995;141:907-915.

34 Nasca PC, Liu S, Baptiste MS, Kwon CS, Jacobson H, Metzger BS: Alcohol consumption and breast cancer: Estrogen receptor status and histology. Am J Epidemiol 1994;140:980-987.

35 Zhang Y, Kreger BE, Dorgan JF, Splansky GL, Cupples LA, Ellison RC: Alcohol consumption and risk of breast cancer: The Framingham study revisited. Am J Epidemiol 1999;149:93101.

36 Longnecker MP: The Framingham results on alcohol and breast cancer. Am J Epidemiol 1999; 149:102-104.

37 Soler M, Chatenoud L, La Vecchia C, Franceschi S, Negri E: Diet, alcohol, coffee and pancreatic cancer: Final results from an Italian study. Eur J Cancer Prev 1998; 7:455-460.

38 De Stefani E, Boffetta P, Carzoglio J, Mendilaharsu S, Deneo-Pellegrini H: Tobacco smoking and alcohol drinking as risk factors for stomach cancer: A case-control study in Uruguay. Cancer Causes Control 1998;9:321-329.

39 Piette JD, Barnett PG, Moos RH: First-time admissions with alcohol-related medical problems: A 10-year follow-up of a national sample of alcoholic patients. J Stud Alcohol 1998;59: 89-96.

40 Lundberg JC, Passik SD: Alcohol and cancer: A review for psycho-oncologists. Psychooncology 1997;6:253-266.

41 Ji BT, Chow WH, Yang G, McLaughlin JK, Gao RN, Zheng W, Shu XO, Jin F, Fraumeni JF Jr, Gay YT: Influence of cigarette smoking, alcohol, and green tea consumption on the risk of carcinoma of the cardia and distal stomach in Shanghai, China. Cancer 1996;77:24492457.

42 Harnack LJ, Anderson KE, Zheng W, Folsom AR, Sellers TA, Kushi LH: Smoking, alcohol, coffee, and tea intake and incidence of cancer of the exocrine pancreas: The Iowa women's health study. Cancer Epidemiol Biomarkers Prev 1997;6:1081-1086.

43 Longnecker MP, Enger SM: Epidemiologic data on alcoholic beverage consumption and risk of cancer. Clin Chim Acta 1996;246:121141.

44 Sarles H, Bernard JP, Johnson CD: Alcohol and the pancreas; in Peters TJ (ed): Alcohol Misuse: A European Perspective. Amsterdam, Harwood Academic Press, 1996, pp 145-161.

45 Ringborg U: Alcohol and risk of cancer. Alcohol Clin Exp Res 1998;22(suppl 7):323S$328 \mathrm{~S}$.

46 Seitz HK, Poschl G, Simanowski UA: Alcohol and cancer. Recent Dev Alcohol 1998;14:6795.

47 Seitz HK, Simanowski UA, Homann N, Waldherr R: Cell proliferation and its evaluation in the colorectal mucosa: effect of ethanol. Z Gastroenterol 1998;36:645-655.

48 Bode C, Bode JC: Alcohol's role in gastrointestinal tract disorders. Alcohol Health Res World 1997;21:76-83.
49 Boutron MC, Faivre J, Dop MC, Quipourt V, Senesse P: Tobacco, alcohol, and colorectal tumors, a multistep process. Am J Epidemiol 1995;141:1038-1046.

50 Gapstur SM, Potter JD, Folsom AR: Alcohol consumption and colon and rectal cancer in postmenopausal women. Int J Epidemiol 1994; 23:50-57.

51 Breslow RA, Weed DL: Review of epidemiologic studies of alcohol and prostate cancer: 1971-1996. Nutr Cancer 1998;30:1-13.

52 Ellison LF, Stokes J, Gibbons L, Lindsay J, Levy I, Morrison H: Monograph series on aging-related diseases: X. Prostate cancer. Chronic Dis Can 1998;19:1-18.

53 Tavani A, Negri E, Franceschi S, Talamini R, La Vecchia C: Alcohol consumption and risk of prostate cancer. Nutr Cancer 1994;21:25-31.

54 Hiatt RA, Armstrong MA, Klatsky AL, Sidney S: Alcohol consumption, smoking, and other risk factors and prostate cancer in a large health plan cohort in California (United States). Cancer Causes Control 1994;5:66-72.

55 Ajani UA, Cook N, Hebert P, Lee I, Manson J, Buring J, Hennekens C: Alcohol consumption and incidence of malignant neoplasms: The Physicians' Health Study. Am J Epidemiol 1998; 147:S45.

56 Putnam SD, Cerhan JR, Parker AS, Wallace RB, Cantor KP, Lynch CF: Alcohol consumption and prostate cancer in a cohort of Iowa males. Am J Epidemiol 1998;147:42.

57 Hayes RB, Brown LM, Schoenberg JB, et al: Alcohol use and prostate cancer risk in US blacks and whites. Am J Epidemiol 1996;143: 692-697.

58 Muscat JE, Wynder EL: A case-control study of risk factors for major salivary gland cancer. Otolaryngol Head Neck Surg 1998;118:195198.

59 Horn-Ross PL, Ljung BM, Morrow M: Environmental factors and the risk of salivary gland cancer. Epidemiology 1997;8:414-419.

60 Parazzini F, La Vecchia C, D'Avanzo B, Moroni S, Chatenoud L, Ricci E: Alcohol and endometrial cancer risk: Findings from an Italian case-control study. Nutr Cancer 1995;23:5562.

61 Newcomb PA, Trentham-Dietz A, Storer BE: Alcohol consumption in relation to endometrial cancer risk. Cancer Epidemiol Biomarkers Prev 1997;6:775-778.

62 Bradley KA, Badrinath S, Bush K, Boyd-Wickizier J, Anawalt B: Medical risks for women who drink alcohol. J Gen Intern Med 1998;13: 627-639.

63 Donato F, Boffetta P, Fazioli R, Aulenti V, Gelatti U, Porru S: Bladder cancer, tobacco smoking, coffee and alcohol drinking in Brescia, northern Italy. Eur J Epidemiol 1997;13: 795-800.

64 Bruemmer B, White E, Vaughan TL, Cheney CL: Fluid intake and the incidence of bladder cancer among middle-aged men and women in a three-county area of western Washington. Nutr Cancer 1997;29:163-168.
65 Yu Y, Hu J, Wang PP, Zou Y, Qu Y, Zhao P, $\mathrm{Xe}$ R: Risk factors for bladder cancer: A casecontrol study in northeast China. Eur J Cancer Prev 1997;6:363-369.

66 Friedman HS: Cardiovascular effects of alcohol; in Galanter M (ed): The Consequences of Alcoholism. New York, Plenum Press, 1998, pp 135-166.

67 Rosenqvist M: Alcohol and cardiac arrhythmias. Alcohol Clin Exp Res 1998;22(suppl 7): 318S-322S.

68 US Department of Health and Human Services: Alcohol use and labor market outcomes; in Secretary of Health and Human Services (ed). 9th Special Report to the US Congress on Alcohol and Health. Rockville, US Department of Health and Human Services, National Institute on Alcohol Abuse and Alcoholism, 1997, pp 289-299.

69 Klatsky AL: Cardiovascular effects of alcohol. Sci Am Sci Med 1995;2:28-37.

70 Curtis AB, Sherman JA, Strogatz DS, Raghunathan TE, Siobán H: Alcohol consumption and changes in blood pressure among African Americans - The Pitt county study. Am J Epidemiol 1997;146:727-733.

71 Keil U, Chambless LE, Döring A, Filipiak B, Stieber J: The relation of alcohol intake to coronary heart disease and all-cause mortality in a beer-drinking population. Epidemiology 1997; 8:150-156.

72 Holman CDAJ, English DR, Milne E, Winter MG: Meta-analysis of alcohol and all-cause mortality: A validation of NHMRC recommendations. Med J Aust 1996;164:141-145.

73 Klatsky AL: Alcohol, coronary heart disease, and hypertension. Annu Rev Med 1996;47: 149-160.

74 Beilin LJ, Puddey IB, Burke V: Alcohol and hypertension - Kill or cure? J Hum Hypertens 1996;10:S1-S5.

75 Corrao G, Bagnardi V, Zambon A, Torchio P: Meta-analysis of alcohol intake in relation to risk of liver cirrhosis. Alcohol Alcohol 1998;33: 381-392.

76 Corrao G, Zambon A, Torchio P, Arico P, Ari co S, La Vecchia C, Di Orio F: Attributable risk for symptomatic liver cirrhosis in Italy. J Hepatol 1998;28:608-614.

77 Corrao G, Arico S, Zambon A, Torchio P, Di Orio F: Female sex and the risk of liver cirrhosis. Collaborative Groups for the Study of Liver Diseases in Italy. Scand J Gastroenterol 1997; 32:1174-1180.

78 Haberman PW, Weinbaum DF: Liver cirrhosis with and without mention of alcohol as cause of death. Br J Addict 1990;85:217-222.

79 Alvear J, Andreani S, Cortés F: Fetal alcohol syndrome and fetal alcohol effects: Importance of early diagnosis and nutritional treatment (in Spanish). Rev Med Chil 1998;126:407-412.

80 Roebuck TM, Mattson SN, Riley EP: A review of the neuroanatomical findings in children with fetal alcohol syndrome or prenatal exposure to alcohol. Alcohol Clin Exp Res 1998;22: 339-344. 
81 Polygenis D, Wharton S, Malmberg C, Sherman N, Kennedy D, Koren G, Einarson TR: Moderate alcohol consumption during pregnancy and the incidence of fetal malformations: A meta-analysis. Neurotoxicol Teratol 1998;20:61-67.

82 Church MW, Eldis F, Blakley BW, Bawle EV: Hearing, language, speech, vestibular, and dentofacial disorders in fetal alcohol syndrome. Alcohol Clin Exp Res 1997;21:227-237.

83 Faden VB, Graubard BI, Dufour M: The relationship of drinking and birth outcome in a US national sample of expectant mothers. Paediatr Perinat Epidemiol 1997;11:167-180.

84 Habbick BF, Snyder RE: Mortality in foetal alcohol syndrome. Can J Public Health 1997 88:181-183.

85 Larkby C, Day N: Effects of prenatal alcohol exposure. Alcohol Health Res World 1997;21: 192-198.

86 Mattson SN, Riley EP, Gramling L, Delis DC, Jones KL: Heavy prenatal alcohol exposure with or without physical features of fetal alcohol syndrome leads to IQ deficits. J Pediatr 1997; 131:718-721.

87 Passaro K-AT, Little RE: Childbearing and alcohol use; in Wilsnack RW, Wilsnack SC (eds): Gender and Alcohol: Individual and Social Perspectives. New Brunswick, Rutgers Center of Alcohol Studies, 1997, pp 90-113.

88 Larroque B, Kaminski M: Alcohol consumption during pregnancy. Ann Epidemiol 1996;6: 169.

89 Passaro KT, Little RE, Savitz DA, Noss J: The effect of maternal drinking before conception and in early pregnancy on infant birthweight. The ALSPAC Study Team. Avon Longitudinal Study of Pregnancy and Childhood. Epidemiology 1996;7:377-383.

90 Windham GC, Fenster L, Hopkins B, Swan $\mathrm{SH}$ : The association of moderate maternal and paternal alcohol consumption with birthweight and gestational age. Epidemiology 1995;6:591597.

91 Shu XO, Hatch MC, Mills J, Clemens J, Susser M: Maternal smoking, alcohol drinking, caffeine consumption, and fetal growth from a prospective study. Epidemiology 1995;6:115120.

92 Alcohol Health and Research World: Special Thematic Issue: Alcohol-Related Birth Defects. Alcohol Health Res World 1994;18(1).

93 Connor PD, Streissguth AP: Effects of prenata exposure to alcohol across the life span. Alcohol Health Res World 1996;20:170-174.

94 Abel EL: Maternal alcohol consumption and spontaneous abortion. Alcohol Alcohol 1997; 32:211-219.

95 Windham GC, Von Behren J, Fenster L, Schaefer C, Swann SH: Moderate maternal alcohol consumption and risk of spontaneous abortion. Epidemiology 1997;8:509-514.

96 Jallon P, Smadja D, Cabre P, Le Mab G, Bazin M, Vernant J-C, Epimart Lg: Crises épileptiques, épilepsies et facteurs de risque: expérience d'une enquête en Martinique. Rev Neurol (Paris) 1998;154:408-411
97 Leone M, Bottacchi E, Beghi E, Morgando E, Mutani R, Amedeo G, Cremo R, Gianelli M, Ravagli Ceroni L, The Alcohol and Epilepsy Study Group: Alcohol use is a risk factor for a first generalized tonic clonic seizure. Neurology 1997;48:614-620.

98 Martín R, Díaz C, Nuévalos C, Matías-Guiu $\mathrm{J}$ : Etiological and prognostic factors in the late onset epilepsy (in Spanish). Rev Neurol 1995; 23:285-289.

99 Skinazi F, Lévy P, Bernades P: Les pancréatites aiguës alcooliques révèlent-elles toujours une pancréatite chronique? Gastroentérol Clin Biol 1995; 19:266-269.

100 Ammann RW, Heitz PU, Klöppel G: Course of alcoholic chronic pancreatitis: A prospective clinicomorphological long-term study. Gastroenterology 1996;111:224-231.

101 Robles-Diaz G, Gorelick FS: Alcohol and acute pancreatitis. Yale J Biol Med 1997;70: 77-87.

102 Thakker KD: An overview of health risks and benefits of alcohol consumption. Alcohol Clin Exp Res 1998;22(suppl):285S-298S

103 Murray CJL, Lopez A: Quantifying the burden of disease and injury attributable to ten major risk factors; in Muray C, Lopez A (eds): The Global Burden of Disease: A Comprehensive Assessment of Mortality and Disability from Diseases, Injuries and Risk Factors in 1990 and Projected to 2020. Boston, Harvard School of Public Health on behalf of the World Health Organization and the World Bank, 1996, pp 295-324.

104 Doll R: The benefit of alcohol in moderation. Drug Alcohol Rev 1998;17:353-363.

105 Hillbom M: Alcohol consumption and stroke: Benefits and risks. Alcohol Clin Exp Res 1998;22(suppl): 352S-358S.

106 Svärdsudd K: Moderate alcohol consumption and cardiovascular disease: Is there evidence for a preventive effect? Alcohol Clin Exp Res 1998;22(suppl):307S-314S

107 Fuchs CS, Stampfer MJ, Colditz GA, Giovannucci EL, Manson JE, Kawachi I, Hunter DJ, Hankinson SE, Hennekens CH, Rosner B, Speizer FE, Willett WC: Alcohol consumption and mortality among women. N Engl J Med 1995;332:1245-1250.

108 Edwards G, Anderson P, Babor TF, Casswell $\mathrm{S}$, Ferrence R, Giesbrecht N, Godfrey C, Holder HD, Lemmens P, Mäkelä K, Midanik LT, Norström T, Österberg E, Romelsjö A, Room R, Simpura J, Skog O-J: Alcohol Policy and the Public Good. Oxford, Oxford University Press, 1994.

109 Jackson R: Cardiovascular disease and alcohol consumption: Evidence of benefits from epidemiologic studies. Contemp Drug Probl 1994;21:5-24.

110 Beaglehole R, Jackson R: Alcohol, cardiovascular diseases and all causes of death: A review of the epidemiological evidence. Drug Alcohol Rev 1992;11:175-290.

111 Goldberg DM, Hahn SE, Parkes JG: Beyond alcohol: Beverage consumption and cardiovascular mortality. Clin Chim Acta 1995;237: 155-187.
112 Hart CL, Smith GD, Hole DJ, Hawthorne VM: Alcohol consumption and mortality from all causes, coronary heart disease, and stroke: Results from a prospective cohort study of Scottish men with 21 years of follow up. BMJ 1999;318:1725-1729.

113 Fillmore KM, Golding JM, Graves KL Kniep S, Leino EV, Romelsjö A, Shoemaker C, Ager CR, Allebeck P, Ferrer HP: Alcohol consumption and mortality. III. Studies of female populations. Addiction 1998;93:219_ 229.

114 Maskarinec G, Meng L, Kolonel LN: Alcohol intake, body weight, and mortality in a multiethnic prospective cohort. Epidemiology 1998;9:654-661.

115 Corrao G, Rubbiati L, Bagnardi V, Zambon A, Poikolainen K: Alcohol and coronary heart disease: A meta-analysis. Addiction 2000;95: 1505-1523.

116 Kitamura A, Iso H, Sankai T, Naito Y, Sato S, Kiyama M, Okamura T, Nakagawa Y, Iida M, Shimamoto T, Komachi Y: Alcohol intake and premature coronary heart disease in urban Japanese men. Am J Epidemiol 1998; 147:59-65.

117 Camargo CA Jr, Hennekens $\mathrm{CH}$, Gaziano JM, Glynn RJ, Manson JE, Stampfer MJ: Prospective study of moderate alcohol consumption and mortality in US male physicians. Arch Intern Med 1997;157:79-85.

118 Rehm J, Bondy SJ, Sempos CT, Vuong CV: Alcohol consumption and coronary heart disease morbidity and mortality. Am J Epidemiol 1997; 146:495-501.

119 Doll R, Peto R, Hall E, Wheatley K, Gray R Mortality in relation to consumption of alcohol: 13 years' observations on male British doctors. BMJ 1994;309:911-918.

120 McElduff P, Dobson AJ: How much alcohol and how often? Population based case-control study of alcohol consumption and risk of a major coronary event. BMJ 1997;314:1159.

121 Bondy SJ: Drinking patterns and their consequences: Report from an international meeting - Overview of studies on drinking patterns and consequences. Addiction 1996;91: 1663-1674.

122 US Department of Health and Human Services: 9th Special Report to the US Congress on Alcohol and Health. Rockville, US Department of Health and Human Services, National Institute on Alcohol Abuse and Alcoholism, 1997.

123 Rankin J: Biological mechanisms at moderate levels of alcohol consumption that may affect coronary heart disease. Contemp Drug Probl 1994;21:45-57.

124 Baraona E, Lieber CS: Alcohol and lipids; in Galanter M (ed): The Consequences of Alcoholism. New York, Plenum Press, 1998, pp 97-134.

125 Friedman HS: Cardiovascular effects of alcohol; in Galanter S (ed): The Consequences of Alhoholism. New York, Plenum Press, 1998, pp 135-166. 
126 Sacco RL, Elkind M, Boden-Albala B, Lin IF, Karman DE, Hauser WA, Shea S, Paik MC: The protective effect of moderate alcohol consumption in ischemic stroke. JAMA 1999;281:53-60.

127 Yuan J-M, Ross RK, Gao Y-T, Henderson BE, Yu MC: Follow-up study of moderate alcohol intake and mortality among middleaged men in Shanghai, China. BMJ 1997;314: 18-23.

128 Wannamethee SG, Shaper AG: Patterns of alcohol intake and risk of stroke in middleaged British men. Stroke 1996;27:10331039.

129 Thun JM, Peto R, Lopez AD, Monaco JH, S.J. H, Heath CW Jr, Doll R: Alcohol consumption and mortality among middle-aged and elderly US adults. N Engl J Med 1997; 337:1705-1714.

130 Knuiman MW, Vu HT: Risk factors for stoke mortality in men and women: The Busselton Study. J Cardiovasc Risk 1996;3:447-452.

131 Berger K, Ajani UA, Kase CS, Gaziano JM, Buring JE, Glynn RJ, Hennekens CH: Lightto-moderate alcohol consumption and the risk of stroke among US male physicians. $\mathrm{N}$ Engl J Med 1999;341:1557-1564.

132 You R, McNeil J, O'Malley H, Davis S, Thrift A, Donnan G: Risk factors for stroke due to cerebral infarction in young adults. Stroke 1997;28:1913-1918.

133 Jackson R: Cardiovascular disease and alcohol consumption: Evidence of benefit from epidemiological studies. Contemp Drug Probl 1994;21:5-24.

134 Rimm EB, Chan J, Stampfer MJ, Colditz GA, Willett WC: Prospective study of cigarette smoking, alcohol use, and the risk of diabetes in men. BMJ 1995;310:555-559.

135 Perry IJ, Wannamethee SG, Walker MK, Thomson AG, Whincup PH, Shaper AG: Prospective study of risk factors for development of non-isulin dependent diabetes in middle aged British men. BMJ 1995;310: 560-564.

136 Ajani UA, Hennekens C, Spelsberg A, Manson JE: Alcohol consumption and risk of type two diabetes mellitus. Am J Epidemiol 1999; 149(suppl):S3.

137 Wei M, Gibbons LW, Mitchell TL, Kampert JB, Blair SN: Alcohol intake and incidence of type 2 diabetes in men. Diabetes Care 2000; 23:18-22.

138 Kao WHL, Brancati FL, Boland LL, Watson RL, Puddey IB: Gender differences in the association of alcohol consumption and the risk of type 2 diabetes mellitus: The Atherosclerosis Risk in Communities (ARIC) study. Am J Epidemiol 1998;147(suppl):S60.
139 Kiechl S, Willeit J, Poewe W, Egger G, Oberhollenzer F, Muggeo M, Bonora E: Insulin sensitivity and regular alcohol consumption: Large, prospective, cross sectional population study (Bruneck study). BMJ 1996;313:10401044.

140 Facchini F, Chen YD, Reaven GM: Light-tomoderate alcohol intake is associated with enhanced insulin sensitivity. Diabetes Care 1994;17:115-119.

141 Mayer EJ, Newman B, Quesenberry CP Jr., Friedman GD, Selby JV: Alcohol consumption and insulin concentrations. Role of insulin in associations of alcohol intake with highdensity lipoprotein choloesterol and triglycerides. Circulation 1993;88:2190-2197.

142 Lazarus R, Sparrow D, Weiss ST: Alcohol intake and insulin levels. The Normative Aging Study. Am J Epidemiol 1997;145:909_ 916.

143 Flanagan DEH, Moore VM, Godsland IF, Cockington RA, Robinson JS, Phillips DI: Alcohol consumption and insulin resistance in young adults. Eur J Clin Invest 2000;30: 297-301.

144 Chen CY, Lu CL, Lee PC, Wang SS, Chang FY, Lee SD: The risk factors for gallstone disease among seniour citizens: An Oriental study. Hepatogastroenterology 1999;46: 1607-1612.

145 Attili AF, Scafato E, Marchioli R, Marfisi RM, Festi D: Diet and gallstones in Italy: The cross-sectional MICOL results. Hepatology 1998;27:1492-1498.

146 Caroli-Bosc FX, Deveau C, Peten EP, Delabre B, Zanaldi $\mathrm{H}$, Hebuterne X, Hastier P, Viudes F, Belanger F, Caroli-Bosc C, Harris A, Hardion M, Rampal P, Delmont JP: Cholelithiasis and dietary risk factors: An epidemiologic investigation in Vidauban, Southeast France. General Practitioner's Group of Vidauban. Dig Dis Sci 1998;43:21312137.

147 Leitzmann MF, Willett WC, Giovannucci EL, Stampfer MJ, Spiegelman D, Colditz GA, Rimm EB: Alcohol intake and the risk of symptomatic gallstones in men. Am J Epidemiol 1998;147:S54.

148 Cherpitel CJ: Alcohol and injuries: A review of international emergency room studies. Addiction 1993;88:923-937.
149 Hingson R, Howland J: Alcohol and non-traffic unintended injuries. Addiction 1993;88: 877-883.

150 Pernanen K: What is meant by 'alcohol-related' consequences?; in Klingemann H, Gmel $\mathrm{G}$ (eds): Mapping the Social Consequences of Alcohol Consumption. Dordrecht, Kluwer Academic Press, 2001, pp 21-31.

151 Rothman KJ, Greenland S: Modern Epidemiology, ed 2. Philadelphia, Lippincott-Raven Press, 1998.

152 Gmel G, Gutjahr E: Alcohol consumption and social harm: Quantitative research methodology; in Klingemann H, Gmel G (eds): Mapping the Social Consequences of Alcohol Consumption. Dordrecht, Kluwer Academic Press, 2001, pp 33-52.

153 Room R: Alcohol consumption and social harm - Conceptual issues and historical perspectives. Contemp Drug Probl 1996;23:373388

154 Eckardt MJ, File SE, Gessa GL, Grant KA Guerri C, Hoffman PL, Kalant H, Koop GF, Li TK, Tabakoff B: Effects of moderate alcohol consumption on the central nervous system. Alcohol Clin Exp Res 1998;22:9981040.

155 Krüger HP, Utzelmann HD, Berghaus G, Kroj G: Effects of low alcohol dosages: A review of the literature; in Krüger HP, Utzelmann HD, Berghaus G, Kroj G (eds): Alcohol, Drugs and Traffic Safety - T'92. Cologne, TÜV Rheinland, 1993, pp 763-778.

156 Rehm J, Ashley MJ, Dubois G: Alcohol and health: Individual and population perspectives. Addiction 1997;92(suppl 1): S109S115.

157 Poikolainen K: It can be bad for the heart, too - Drinking patterns and coronary heart disease. Addiction 1998;93:1757-1759.

158 Walsh G, Rehm J: Daily drinking and harm. Contemp Drug Probl 1996;23:465-478.

159 Gmel G, Klingemann S, Müller R, Brenner $\mathrm{D}$ : Revising the preventive paradox: The Swiss case. Addiction 2001;96:273-284.

160 Stockwell T, Hawks D, Lang E, Rydon P: Unravelling the preventive paradox for acute alcohol problems. Drug Alcohol Rev 1996;15: $7-15$.

161 Hall W: Changes in the public perceptions of the health benefits of alcohol use, 1989-1994. Aust NZ J Public Health 1996;20:93-95.

162 Rehm J, Gmel G, Room R, Frick U: Average volume of alcohol consumption, drinking patterns and related burden of mortality in young people in established market economies of Europe. Eur Addict Res 2001:7:148151. 